\title{
CXCR4+ and SDF-1+ Bone Marrow Cells Are Mobilized into the Blood Stream in Acute Myocardial Infarction and Acute Ischemia
}

\author{
José Luis Aceves ${ }^{1 *}$, Rafael Vilchis ${ }^{1}$, María Antonieta Medina ${ }^{2}$, Monserrat Borja ${ }^{1}$, \\ Silvia Cortes ${ }^{3}$, Guillermo Díaz ${ }^{1}$, Armando Castro' ${ }^{1}$, Alexis Gómez ${ }^{1}$, José J. Parra ${ }^{1}$, \\ Martha Alvarado², Manuel López Hernández², Virna Poveda4, Felipe Masso², \\ Luis F. Montaño ${ }^{4}$ \\ ${ }^{1}$ División de Cardiocirugía, Centro Médico Nacional 20 de Noviembre ISSSTE, México DF, México \\ ${ }^{2}$ Departamento de Hematología, Centro Médico Nacional 20 de Noviembre ISSSTE, México DF, México \\ ${ }^{3}$ Laboratorio de Hormonas, Centro Médico Nacional 20 de Noviembre ISSSTE, México DF, México \\ ${ }^{4}$ Departamento de Inmunobiología Biología Celular y Tisular, Facultad de Medicina UNAM, México DF, México \\ Email: ${ }^{*}$ acevesch@hotmail.es
}

Received 16 April 2014; revised 28 May 2014; accepted 13 June 2014

Copyright (C) 2014 by authors and Scientific Research Publishing Inc.

This work is licensed under the Creative Commons Attribution International License (CC BY). http://creativecommons.org/licenses/by/4.0/

c) (i) Open Access

\section{Abstract}

Cell therapy has shown beneficial effects on ventricular function and tissue regeneration in patients with acute and chronic myocardial infarction, although with diverse grades of variability in the results, possibly by proportion, subtype and cell cycle status. Objective: Identify and phenotypically characterize, via CXCR4 and SDF-1 expression, the bone marrow cell subpopulations that are mobilized into the bloodstream in patients with Acute Myocardial Infarction (AMI) and Acute Ischemia (AI) such as acute angina and Chronic Ischemia (CI) such as chronic stable angina, and also determine the cell cycle status of these cells. Method: Patients with AMI and AI were recruited in the ICCU, and patients with $\mathrm{CI}$ in the departments of cardiology and cardiovascular surgery. The quantification of cellular subpopulations was made by cytofluorometry with a FACS caliburcyto fluorometry (Becton Dickinson) with specific FITC-labeled anti human monoclonal antibodies against CD34, CD133, CD117, CD48, CXCR4, SDF-1 and Ki67 (Becton Dickinson). Serum concentration of IL- 6 and IL-8 were determined by a sequential solid phase chemiluminescent assay performed in a SIEMENS IMMULITE 1000 Analyzer. Statistical analysis was made with the SPSS version 20.0 for Windows. A $p$ value $<0.05$ was considered as statistical significant. Results: We analyzed 174 patients. 67 had Acute Myocardial Infarction, 55 Acute Ischemia and 52 Chronic Ischemia. Total cellularity of bone marrow and SDF-1+ cells was significantly higher in patients with AMI $\left(14.6 \pm 1.5 \times 10^{3} / \mathrm{ml}\right)$ than that in AI $\left(9.2 \pm 1.3 \times 10^{3} / \mathrm{ml}\right)$ and CI $\left(6.6 \pm 1.1 \times 10^{3} / \mathrm{ml}\right)$ patients $(p$

\footnotetext{
*Corresponding author.
}

How to cite this paper: Aceves, J.L., et al. (2014) CXCR4+ and SDF-1+ Bone Marrow Cells Are Mobilized into the Blood Stream in Acute Myocardial Infarction and Acute Ischemia. World Journal of Cardiovascular Diseases, 4, 361-367. 
$<0.001)$. There were no significant differences in the amount of CD34+, CD117+, CD133+ and CD48+ cells between AMI $(49.9 \pm 3.9,45 \pm 4.7,43.2 \pm 3.7,35.4 \pm 6.7$ respectively) and AI (36.7 \pm 2.5 , $36 \pm 3.2,33.7 \pm 5.1,32 \pm 5$ respectively) patients ( $p=0.22$ to 0.39 ), but interestingly in AMI and AI patients, cells were CXCR4+ in almost half of these mobilized cells, although the proportion was significantly higher in AMI patients $(46.8 \% \pm 7.1 \%$ to $55.7 \% \pm 6.3 \%$ vs $23 \% \pm 1.6 \%$ to $28.4 \% \pm$ $2.1 \%, p=0.03$ to 0.05$)$. A similar behavior was observed with the Ki67 antibody $(29.9 \% \pm 2.1 \%$ to $36.1 \% \pm 6.3 \%$ vs $10 \% \pm 1.2 \%$ to $24 \% \pm 1.1 \%, p=0.001$ to 0.05 ). Bivariate analysis of the results showed a significant correlation of the cell proportion in AMI but not in AI and CI patients $(p=$ 0.001 to $0.05 ; 0.12$ to 0.87 and 0.17 to 0.92 respectively). The amount of myocardial tissue infarcted did not show any correlation with the amount of cellular subpopulations mobilized to peripheral blood ( $r=0.10$ to $0.20 ; p=0.21$ to 0.64$)$ from the bone marrow. Conclusion: The proportion of cellular subpopulations with regenerative potential mobilized to circulation during an event of Acute Myocardial Infarction is significantly higher than during an event of acute angina and chronic stable angina, with a significant proportion of mobilized cells that expressed CXCR4, most of which were already in some of the cell cycle phases.

\section{Keywords}

Stem Cells, CXCR4:SDF-1 Axis, Cardiac Repair, Acute and Chronic Ischemia

\section{Introduction}

The concept that the heart is unable to regenerate has been invalidated with the emergence of cell therapy, however, and despite multiple clinical trials, it has been difficult to elucidate which subpopulations of bone marrow stem cells, are related to ventricular function improvement, reduction of infarct size, tissue regeneration and angiogenesis [1]-[5].

The cellular necrosis process triggers acute inflammatory events with local accumulation of polymorphonuclear cells and acute phase cytokines such as interleukins and Stem Cell Derived Factor 1 (SDF-1). The latter has shown increases up to 50-fold in the infarct process in experimental models [6]-[9].

The SDF-1:CXCR4 axis acts upon bone marrow to release stem cells to the blood circulation, especially those which express CXCR4, that are then recruited in the myocardial injured. Several experimental studies of myocardial infarction have determined a great variety of stem cells with regenerative and angiogenic activity. These cells usually express CD34, CD133, CD117 and their regenerative capacity is enhanced in the presence of growth factors produced by CD48 stem cells [10]-[14].

Cell therapy has shown beneficial effects on ventricular function and tissue regeneration in patients with acute and chronic myocardial infarction, although with considerable variability in the results, possibly as a consequence of cell proportion, subtype and status of the cells in the cellular cycle, or maybe, by different inflammatory conditions in the heart when cellular implantation is performed [4] [13]-[17]. In order to try to improve the efficacy of cellular therapy, our aim was to identify and phenotypically characterize, via CXCR4 and SDF-1 expression, the bone marrow cell subpopulations that are mobilized into the bloodstream in a severe inflammatory event, such as Acute Myocardial Infarction (AMI) and acute angina, as well as determine the cell cycle status of these cells.

\section{Method}

The study was approved by the hospital research and ethic committees. Patients with myocardial infarction and acute ischemia such as acute angina admitted in the Intensive Coronary Care Unit (ICCU) were recruited and patients with Chronic Ischemia such as chronic stable angina in cardiology and cardiovascular surgery departments were recruited. All of them signed an informed consent. During the first 6 hours of stay of patients with AMI and AI in ICCU, a $10 \mathrm{ml}$ blood sample was obtained from the cephalic vein: $5 \mathrm{ml}$ were collected in an EDTA-containing tube whereas the remaining $5 \mathrm{ml}$ were kept in a non-anticoagulant-containing tube. A similar amount of blood sample was obtained in patients with chronic stable angina (Chronic Ischemia) during hospitalization. All samples were kept at $4^{\circ} \mathrm{C}$. 


\subsection{Patients Cardiac Evaluation}

At arrival to the Intensive Coronary Care Unit, age, gender and cardiovascular risk factors were carefully identified. In all patients upon arrival was taken a 12 derivations electrocardiogram as well as a serum determination of Creatine Kinase-MB and troponine I. All the patients had an echocardiographic study made with a vivid-q echocardiograph with a M4S-RS transducer, for quantification of regional myocardial motility through Bull'seye map construction by the following projections: Long axis (APLAX), 2 and 4 cameras.

\subsection{Isolation and Phenotipification of Cellular Subpopulations}

Peripheral blood mononuclear cells were isolated from the $5 \mathrm{ml}$ through centrifugation for 10 minutes at 250 RPM and the supernatant discarded by adding $500 \mu$ l buffer solution. The remaining cells were labeled with specific antibodies and incubated with permeabilizing solution for 10 minutes, then were centrifuged at 250 RPM and kept under refrigeration at $4^{\circ} \mathrm{C}$ for 30 minutes.

By cytofluorometry with a FACS caliburcytofluorometer (Becton Dickinson) with a specific FITC-labeled anti human (CD34, CD133, CD117 and CD48) monoclonal antibody (Becton Dickinson) were estimated the percentages as well as the proportions of their cells which expressed CXCR4.

\subsection{Quantification of Inflammatory Markers and Determining Cell Cycle Status}

Serum concentration of IL-6 and IL-8 were determined by enzyme immunometric assay sequential solid phase chemiluminesce performed in an automated fashion, with a SIEMENS IMMULITE 1000 Analyzer. The levels of Stem Derived Factor-1 (SDF-1) were indirectly determined by cytofluorometry with a FACS caliburcytofluorometer (Becton Dickinson) using a specific FITC-labeled anti human CD184 monoclonal antibody (Becton Dickinson). The status of the cells subpopulations in the cellular cycle was identified with specific antibodies againts Ki67 (Clon7B11, CEIVD) by flow cytometry (Cytometer Bencton Dikinson 4 channels).

\section{Statistical Analysis}

All patients included in the study were divided in 3 groups: 1) Patients with Acute Myocardial Infarction (AMI); 2) Acute Ischemia (AI) such as acute angina and 3) Chronic Ischemia (CI) such as chronic stable angina. For descriptive analysis we used media and DE. The comparisons between groups were made with Student $t$ test for two groups and ANOVA for three groups. For correlation analysis the Spearman Rho test was used. Nominal variables were analyzed with a Chi2 test. We consider statistical significance with a $p$ value of $<0.05$. The Statistical software SPSS v 20.0 for Windows was used.

\section{Results}

We analyzed patients with Acute Myocardial Infarction $(n=67)$, Acute Ischemia such as acute angina $(n=55)$ and Chronic Ischemia such as chronic stable angina $(n=52)$. We did not observe significant differences between groups in age, cardiovascular disease risk factors and amount of myocardial tissue damaged as determined by the echocardiographic study (Table 1). Patients with AMI showed significant higher levels of isoenzime CK$\mathrm{MB}$ and tropinine I in comparison with $\mathrm{AI}$ and CI patients groups (88 $\pm 12 \mathrm{u} / \mathrm{l} \mathrm{vs} 7.2 \pm 1.5 \mathrm{u} / \mathrm{l} \mathrm{vs} 3.4 \pm 1.2 \mathrm{u} / \mathrm{l}$ respectively, $p<0.001)$. All patients in group AMI and AI showed the expected electrocardiographic changes (S-T segment elevation).

The inflammatory cytokines no showed statistical significance between AMI and AI patients, but were significantly higher than CI: IL-6 in AMI $41.4 \pm 9.8$ pg/ml; AI $40.8 \pm 9.7 \mathrm{pg} / \mathrm{ml}, p=0.73$. AC $9.6 \pm 3.1 \mathrm{pg} / \mathrm{ml}, p=$ 0.001. IL-8 in AMI $45.6 \pm 8.2 \mathrm{pg} / \mathrm{ml}$; AI $43.4 \pm 7.4 \mathrm{pg} / \mathrm{ml}, p=0.67$; CI $8.9 \pm 2.7 \mathrm{pg} / \mathrm{ml}, p=0.001$.

The total amount of cells mobilized into the blood stream was significantly higher in patients with AMI compared with AI and CI patients. The amount of CD34+, CD117+, CD48+ and CD133+ cells showed not significant differences between AMI and AI patients. Interestingly, and despite the apparent lack of differences, the amount of CXCR4+ cells in the AMI patients were significantly higher than those of the AI and CI patients $(p<$ 0.02 to 0.05 and 0.001 respectively). Nearly $40 \%(29.9 \% \pm 2.1 \%$ to $39.1 \% \pm 7.5 \%)$ of the CXCR4+ cells in the AMI patients were Ki67+ (Table 2).

The bivariate analysis showed a significant correlation of the proportional amount of cells positive for the 
Table 1. Cardiovascular disease factor risk and amount of myocardial tissue affected.

\begin{tabular}{ccccc}
\hline & AMI $(n=67)$ & AI $(n=55)$ & CI $(n=52)$ & $p$ \\
\hline Age (years) & $65 \pm 11$ & $62 \pm 10$ & $64 \pm 9$ & $0.84^{*}$ \\
Diabetes Mellitus & 24 & 20 & 24 & $0.18^{* *}$ \\
Evolution in years & $7 \pm 4$ & $8 \pm 2$ & $8 \pm 3$ & $0.93^{*}$ \\
Hypertension & 18 & 15 & 26 & $0.47^{* *}$ \\
Evolutión in years & $5 \pm 2$ & $6 \pm 2$ & $5 \pm 3$ & $0.68^{*}$ \\
Dyslipidemia & 13 & 9 & 18 & $0.15^{* *}$ \\
Evolutión in years & $3 \pm 1$ & $4 \pm 1$ & $3 \pm 1$ & $0.77^{*}$ \\
Segments affected (n) & $4.2 \pm 0.7$ & $\mathrm{NV}$ & $3.9 \pm 0.4$ & $25 \pm 3$ \\
Tissue Infarcted & $23 \pm 4$ & $\mathrm{NV}$ & $0.34 \&$ & $0.27^{*}$
\end{tabular}

Patients with diabetes mellitus, hypertension and dislipidemia are expressed in percentages of total patients in each group, as well as the tissue infarcted; AMI: Acute Myocardial Infarction; AI: Acute Ischemia; CI: Chronic Ischemia; NV: No Value. ${ }^{*}$ ANOVA; ${ }^{* *} \mathrm{X}^{2}$; \&: Student t test.

Table 2. Bone Marrow Subpopulations cells, inflammatory SDF-1 and state in cellular cycle (Ki67).

\begin{tabular}{cccccc}
\hline & AMI & AI & $p^{*}$ & CI & $p(\&)$ \\
\hline Cells $\times 10^{3} / \mathrm{ml}$ & $14.6 \pm 1.5$ & $9.2 \pm 1.3$ & 0.001 & $6.6 \pm 1.1$ & 0.001 \\
SDF-1 & $48.9 \pm 5.7$ & $32.5 \pm 5.2$ & 0.03 & $3.7 \pm 1.3$ & 0.001 \\
& & & & \\
CD48+ & $35.4 \pm 6.7$ & $32 \pm 5$ & 0.39 & $2.2 \pm 0.09$ & 0.001 \\
CXCR4 & $43.2 \pm 4.9$ & $28.4 \pm 2.1$ & 0.05 & $0.30 \pm 0.01$ & 0.001 \\
KI67 & $29.9 \pm 2.1$ & $20.1 \pm 4.2$ & 0.05 & $5.2 \pm 0.8$ & 0.001 \\
CD34+ (\%) & $49.9 \pm 3.9$ & $36.7 \pm 2.5$ & 0.35 & $4.5 \pm 1.5$ & 0.001 \\
CXCR4 & $55.7 \pm 6.3$ & $27.9 \pm 3.4$ & 0.03 & $2.8 \pm 0.6$ & 0.001 \\
KI67 & $36.3 \pm 3.6$ & $16.3 \pm 1.2$ & 0.02 & $1.8 \pm 0.02$ & 0.001 \\
CD117+ & $45 \pm 4.7$ & $36 \pm 3.2$ & 0.37 & $4.4 \pm 1.5$ & 0.001 \\
CXCR4 & $49.7 \pm 6.3$ & $23 \pm 1.6$ & 0.03 & $1.1 \pm 1.9$ & 0.001 \\
KI67 & $39.1 \pm 7.5$ & $24 \pm 1.1$ & 0.03 & $0.7 \pm 0.3$ & 0.001 \\
CD133+ & & & & \\
CXCR4 & $43.2 \pm 3.7$ & $33.7 \pm 5.1$ & 0.38 & $3.9 \pm 1.5$ & 0.001 \\
KI67 & $46.8 \pm 7.1$ & $25.6 \pm 2.8$ & 0.03 & $2.07 \pm 0.67$ & 0.001 \\
\hline
\end{tabular}

All the results are expressed as percentage of positive cells in comparison with the total cell count. AMI: Acute Myocardial Infarction; AI: Acute Ischemia; CI: Chronic Ischemia; \&: AMI vs AI vs IC comparison; ${ }^{*}$ AMI vs AI comparison; Cellular proportion which express SDF-1 linked to CD184 (CXCR4); Comparisonwith $\mathrm{X}^{2}$ test.

CD's that we evaluated with SDF-1 expressing in AMI patients ( $p<0.01$ a 0.04$)$ but not in AI or CI patients $(p=$ 0.12 to 0.87 and 0.17 to 0.92 respectively) (Table 3). Evidently the levels of CK-MB and Troponine I only showed a significant correlation with AMI patients $\left(r_{s}=0.68, p=0.01 ; r_{s}=0.65, p=0.01\right.$ respectively). The amount of myocardial tissue infarcted did not correlated with the cellular populations mobilized to peripheral blood ( $r=0.10$ to $0.20 ; p=0.21$ to 0.64$)$.

\section{Discussion}

Cardiac repair and restraint of fibrosis are the consequence of the delivery of progenitor cells into ischemic cardiac muscle, which promotes angiogenesis and revascularization [4] [9] [18]-[20]. These effects have been observed in patients with Acute Myocardial Infarctions with viable tissue as well as in patients with a vast scar as a consequence of an old heart infarction episode [4] [14]-[16]. Variations in the function of the infarcted heart after cell therapy can be secondary to differences of the implanted progenitor cells [15] [16], so we conducted this study to determine the bone marrow cell populations that move in acute and chronic is chemia events such as Acute Myocardial Infarction, acute angina and chronic stable angina respectively. Our results show that the amount and phenotype of the progenitor cells that are liberated into the blood stream vary according to the pa- 
Table 3. Correlation between cell mobilization and SDF-1.

\begin{tabular}{|c|c|c|c|c|c|c|}
\hline & \multicolumn{2}{|c|}{ AMI } & \multicolumn{2}{|c|}{$\mathrm{AI}$} & \multicolumn{2}{|c|}{ CI } \\
\hline & $r$ & $p$ & $r$ & $p$ & $r$ & $p$ \\
\hline CD117 & 0.65 & 0.02 & 0.38 & 0.19 & 0.21 & 0.17 \\
\hline CXCR4 & 0.67 & 0.01 & 0.61 & 0.17 & 0.10 & 0.49 \\
\hline KI67 & 0.59 & 0.001 & 0.32 & 0.26 & 0.01 & 0.91 \\
\hline CD133 & 0.81 & 0.03 & 0.39 & 0.22 & 0.01 & 0.92 \\
\hline CXCR4 & 0.66 & 0.03 & 0.27 & 0.40 & 0.08 & 0.57 \\
\hline KI67 & 0.90 & 0.02 & 0.25 & 0.87 & 0.03 & 0.81 \\
\hline CD34 & 0.61 & 0.03 & 0.13 & 0.59 & 0.02 & 0.86 \\
\hline CXCR4 & 0.90 & 0.02 & 0.10 & 0.12 & 0.12 & 0.42 \\
\hline KI67 & 0.65 & 0.01 & 0.11 & 0.55 & 0.03 & 0.42 \\
\hline CD48 & 0.45 & 0.12 & 0.19 & 0.35 & 0.16 & 0.31 \\
\hline CXCR4 & 0.67 & 0.01 & 0.32 & 0.27 & 0.07 & 0.65 \\
\hline KI67 & 0.51 & 0.03 & 0.26 & 0.36 & 0.10 & 0.50 \\
\hline CD90 & 0.43 & 0.05 & 0.33 & 0.22 & 0.14 & 0.37 \\
\hline CXCR4 & 0.49 & 0.05 & 0.19 & 0.43 & 0.10 & 0.48 \\
\hline KI67 & 0.45 & 0.04 & 0.12 & 0.28 & 0.11 & 0.46 \\
\hline
\end{tabular}

AMI: Acute Myocardial Infarction; AI: Acute Ischemia; CI: Chronic Ischemia. Correlation with Spearman Rho.

thology, especially the amount of SDF-1 positive cells circulating and mobilized cells during the early hours of an Acute Myocardial Infarction event, which are completely different to those of an acute angina event and chronic stable angina.

Stromal cell derived factor (SDF-1)-1, acts as a releasing factor for stem cells CXCR4+ in the bone marrow and recruit these stem cells CXCR4+ in the injured tissue [7] [21] because SDF-1 is the natural ligand for CXCR4 [7] [10], and there is increasing evidence about the importance of the SDF-1:CXCR4 axis in the regulation of myocardial repair following ischemic injury [10]. Our findings corroborate the importance of this axis since we observed a significant increase of bone marrow-derived cells which express CXCR4 especially in patients with Acute Myocardial Infarction, compared with patients with acute angina (Acute Ischemia) and Chronic stable angina (Chronic Ischemia). In these latter patients, we also observed CXCR4 positive cells, probably because the SDF-1:CXCR4 axis is partially activated as a consequence of hypoxia in the myocardial cells or the presence of inflammatory interleukins.

The differences observed in cellular subpopulations derived from the bone marrow that express CXCR4, may also be explained for the probable over activation of the SDF-1:CXCR4 axis. There are evidence that support the hypothesis that the temporal alignment of this axis is modified by acute hypoxia and cell death [7] [22]-[25], so that the ischemic phenomenon, such as Acute Myocardial Infarction and acute angina, could be modifiers of this axis.

Inflammatory cytokines increase the presence of bone marrow cell subpopulations [26], however, our findings showed no significant differences in the level of interleukin-6 and 8 among acute angina and AMI patients. Nevertheless our findings do not evade their substantial importance because it is well known that acute ischemic events promote the release of growth factors by CD48 cells via IL-6 and IL-8 [27]. This CD48 cell population has been considered as important factor in the process of infarcted myocardial tissue repair [20] [25].

So far no clinical trials evaluating the efficacy of stem cells derived from the bone marrow in cardiac repair concerning to cell status on cell cycle. This apparently irrelevant information could explain the variations in the results of cardiac regeneration reported in different publications. Our findings show that in patients with Acute Myocardial Infarction, the proportion of cells that express Ki67 which were released into the circulation is significantly higher than in patients with acute angina that did not reach cellular necrosis. This suggests that many cells are released from bone marrow in process of active cell division. This observation reinforces the need to consider this information if we want to improve the cellular therapy efficacy in patients with acute and Chronic Ischemia.

The phenotypic characterization of cellular subpopulations derived from the bone marrow shows that there 
are three aspects to consider in order to improve cellular therapy for myocardial repair after an infarct event: 1) We must consider the proportion of cells expressing the cell markers involved in tissue repair and angiogenesis (CD34, CD117, CD48, CD133), 2) The proportion of cells that express the CXCR4 marker, and 3) Their cell cycle status.

In summary, our results confirm that the SDF-1 CXCR4 axis reported by Tang et al. [7] has an important role in the genesis of myocardial regeneration after an infarct event. This axis together with the presence of inflammatory interleukins activate pathways that mobilize cells with regenerative and angiogenic capacity. Our findings also show that there are different proportions of bone marrow-derived cell populations that are mobilized into the circulation during an event of Acute Myocardial Infarction, especially cells that express CXCR4 and are in an active proliferating status. We believe that our results should or could improve the efficacy of cell therapy for the regeneration of infarcted myocardial tissue; similarly, these results open new possibilities to cell regenerative therapy as far as to consider concerned specific aspects of cell mobilization during acute and Chronic Ischemia.

\section{Conclusion}

The proportion of cellular subpopulations with regenerative potential mobilized to circulation during an event of Acute Myocardial Infarction is significantly higher than during an event of acute angina and chronic stable angina with a significant proportion of cells expressing CXCR4, most of which were already in some of the cell cycle phases.

\section{References}

[1] Kajstura, J., Leri, A., Castaldo, C., Nadal-Ginard, B. and Anversa, P. (2004) Myocyte Growth in the Failing Heart. Surgical Clinics of North America, 84, 161-177. http://dx.doi.org/10.1016/S0039-6109(03)00215-9

[2] Timmermans, F., De Sutter, J. and Gillebert, T.C. (2003) Stem Cells for the Heart, Are We There Yet? Cardiology, 100, 176-185. http://dx.doi.org/10.1159/000074811

[3] Urbanek, K., Quaini, F., Tasca, G., Torella, D., Castaldo, C., Nadal-Ginard, B., Leri, A., Kajstura, J., Quaini, E. and Anversa, P. (2003) Intense Myocyte Formation from Cardiac Stem Cells in Human Cardiac Hypertrophy. Proceedings of the National Academy of Sciences of the United States of America, 100, 10440-10445. http://dx.doi.org/10.1073/pnas.1832855100

[4] Assmus, B., Schachinger, V., Teupe, C., Britten, M., Lehmann, R., Dobert, N., Grunwald, F., Aicher, A., Urbich, C., Martin, H., Hoelzer, D., Dimmeler, S. and Zeiher, A.M. (2002) Transplantation of Progenitor Cells and Regeneration Enhancement in Acute Myocardial Infarction (TOPCARE-AMI). Circulation, 106, 3009-3017. http://dx.doi.org/10.1161/01.CIR.0000043246.74879.CD

[5] Vulliet, P.R., Greeley, M., Halloran, S.M., MacDonald, K.A. and Kittleson, M.D. (2004) Intra-Coronary Arterial Injection of Mesenchymal Stromal Cells and Microinfarction in Dogs. Lancet, 363, 783-784. http://dx.doi.org/10.1016/S0140-6736(04)15695-X

[6] Zhang, G., Nakamura, Y., Wang, X., Hu, Q., Suggs, L.J. and Zhang, J. (2007) Controlled Release of Stromal Cell-Derived Factor-1 Alpha in Situ Increases c-Kit Cell Homing to the Infarcted Heart. Tissue Engineering, 13, 2063-2071. http://dx.doi.org/10.1089/ten.2006.0013

[7] Tang, Y.L., Zhu, W., Cheng, M., Chen, L., Zhang, J., Sun, T., et al. (2009) Hypoxic Preconditioning Enhances the Benefit of Cardiac Progenitor Cell Therapy for Treatment of Myocardial Infarction by Inducing CXCR4 Expression. Circulation Research, 104, 1209-1216. http://dx.doi.org/10.1161/CIRCRESAHA.109.197723

[8] Jane-wit, D., Altuntas, C.Z., Johnson, J.M., Yong, S., Wickley, P.J. and Clark, P. (2007) Beta 1-Adrenergic Receptor Autoantibodies Mediate Dilated Cardiomyopathy by Agonistically Inducing Cardiomyocyte Apoptosis. Circulation, 116, 399-410. http://dx.doi.org/10.1161/CIRCULATIONAHA.106.683193

[9] Assmus, B., Fischer-Rasokat, U., Honold, J., Seeger, F.H., Fichtlscherer, S. and Tonn, T. (2007) Transcoronary Transplantation of Functionally Competent BMCs Is Associated with a Decrease in Natriuretic Peptide Serum Levels and Improved Survival of Patients with Chronic Postinfarction Heart Failure: Results of the TOPCARE-CHD Registry. Circulation Research, 100, 1234-1241. http://dx.doi.org/10.1161/01.RES.0000264508.47717.6b

[10] Penn, M.S. (2009) Importance of the SDF-1:CXCR4 Axis in Myocardial Repair. Circulation Research, 104, 11331135. http://dx.doi.org/10.1161/CIRCRESAHA.109.198929

[11] Lévesque, J.P., Hendy, J., Winkler, I.G., Takamatsu, Y. and Simmons, P.J. (2003) Granulocyte Colony-Stimulating Factor Induces the Release in the Bone Marrow of Pro-Teases That Cleave c-KIT Receptor (CD117) from the Surface 
of Hematopoietic Progenitor Cells. Experimental Hematology, 31, 109-117. http://dx.doi.org/10.1016/S0301-472X(02)01028-7

[12] Brunskill, S.J., Hyde, C.J., Doree, C.J., Watt, S.M. and Martin-Rendon, E. (2009) Route of Delivery and Baseline Left Ventricular Ejection Fraction, Key Factors of Bone-Marrow-Derived Cell Therapy for Ischaemic Heart Disease. European Journal of Heart Failure, 11, 887-896. http://dx.doi.org/10.1093/eurjhf/hfp101

[13] Yeh, E.T., Zhang, S., Wu, H.D., Korbling, M., Willerson, J.T. and Estrov, Z. (2003) Transdifferentiation of Human Peripheral Blood CD34-Enriched Cell Population into Cardiomyocytes, Endothelial Cells, and Smooth Muscle Cells in Vivo. Circulation, 108, 2070-2073. http://dx.doi.org/10.1161/01.CIR.0000099501.52718.70

[14] Suarez de Lezo, J., Herrera, C., Pan, M., Romero, M., Pavlovic, D., Segura, J., Sanchez, J., Ojeda, S. and Torres, A. (2007) Regenerative Therapy in Patients with a Revascularized Acute Anterior Myocardial Infarction and Depressed Ventricular Function. Revista Española de Cardiología, 60, 357-365.

[15] Archundia, A., Aceves, J.L., Lopez-Hernandez, M., Alvarado, M., Rodriguez, E., Diaz Quiroz, G., Paez, A., Rojas, F.M. and Montaño, L.F. (2005) Direct Cardiac Injection of G-CSF Mobilized Bone-Marrow Stem-Cells Improves Ventricular Function in Old Myocardial Infarction. Life Sciences, 78, 279-283. http://dx.doi.org/10.1016/j.lfs.2005.04.080

[16] Aceves, J.L., Archundia, A., Paez, A., Vilchis, R., Varela, E. and Rodriguez, E. (2012) Efficacy and Long-Term Evaluation of Intramyocardial Injection of Autologous CD34-Enriched PBMSC in Old Myocardial Infarction. World Journal of Cardiovascular Diseases, 2, 283-290. http://dx.doi.org/10.4236/wjcd.2012.24044

[17] Bartunek, J., Dimmeler, S., Drexler, H., Fernandez-Aviles, F., Galinanes, M. and Janssens, S. (2006) Task Force of the European Society of Cardiology. The Consensus of the Task Force of the European Society of Cardiology Concerning the Clinical Investigation of the Use of Autologous Adult Stem Cells for Repair of the Heart. European Heart Journal, 27, 1338-1340. http://dx.doi.org/10.1093/eurheartj/ehi793

[18] Strauer, B.E., Brehm, M., Zeus, T., Kostering, M., Hernandez, A., Sorg, R.V., et al. (2002) Repair of Infarcted Myocardium by Autologous Intra-Coronary Mononuclear Bone Marrow Cell Transplantation in Humans. Circulation, 106, 1913-1918. http://dx.doi.org/10.1161/01.CIR.0000034046.87607.1C

[19] Mathur, A. and Martin, J.F. (2004) Stem Cells and Repair of the Heart. Lancet, 364, 183-192. http://dx.doi.org/10.1016/S0140-6736(04)16632-4

[20] Tse, H.F., Kwong, Y.L., Chan, J.K., Lo, G., Ho, C.L. and Lau, C.P. (2003) Angiogenesis in Ischaemic Myocardium by Intramyocardial Autologous Bone Marrow Mononuclear Cell Implantation. Lancet, 361, 47-49. http://dx.doi.org/10.1016/S0140-6736(03)12111-3

[21] Askari, A., Unzek, S., Popovic, Z.B., Goldman, C.K., Forudi, F., kiedrowski, M., Rovner, A., Ellis, S.G., Thomas, J.D., DiCorleto, P.E., Topol, E.J. and Penn, M.S. (2003) Effect of Stromal-Cell-Derived Factor-1 on Stem Cell Homing and Tissue Regeneration in Ischemic Cardiomyopathy. Lancet, 362, 697-703. http://dx.doi.org/10.1016/S0140-6736(03)14232-8

[22] Schachinger, V., Erbs, S., Elsasser, A., Haberbosch, W., Hambrecht, R., Holschermann, H., Yu, J., Corti, R., Mathey, D.G., Hamm, C.W., Suselbeck, T., Assmus, B., Tonn, T., Dimmeler, S. and Zeiher, A.M. (2006) Intracoronary Bone Marrow Derived Progenitor Cells in Acute Myocardial Infarction. The New England Journal of Medicine, 355, 12101221. http://dx.doi.org/10.1056/NEJMoa060186

[23] Hu, X., Dai, S., Wu, W.J., Tan, W., Zhu, X., Mu, J., Guo, Y., Bolli, R. and Rokosh, G. (2007) Stromal Cell Derived Factor-1 Alpha Confers Protection against Myocardial Ischemia/Reperfusion Injury: Role of the Cardiac Stromal Cell Derived Factor-1 Alpha CXCR4 Axis. Circulation, 116, 654-663. http://dx.doi.org/10.1161/CIRCULATIONAHA.106.672451

[24] Zagzag, D., Lukyanov, Y., Lan, L., Ali, M.A., Esencay, M., Mendez, O., Yee, H., Voura, E.B. and Newcomb, E.W. (2006) Hypoxia-Inducible Factor 1 and VEGF Upregulate CXCR4 in Glioblastoma: Implications for Angiogenesis and Glioma Cell Invasion. Laboratory Investigation, 86, 1221-1232. http://dx.doi.org/10.1038/labinvest.3700482

[25] Phillips, R.J., Mestas, J., Gharaee-Kermani, M., Burdick, M.D., Sica, A., Belperio, J.A., Keane, M.P. and Strieter, R.M. (2005) Epidermal Growth Factor and Hypoxia-Induced Expression of CXC Chemokine Receptor 4 on Non-Small Cell Lung Cancer Cells Is Regulated by the Phosphatidylinositol 3-Kinase/PTEN/AKT/Mammalian Target of Rapamycin Signaling Pathway and Activation of Hypoxia Inducible Factor-1 Alpha. The Journal of Biological Chemistry, 280, 22473-22481. http://dx.doi.org/10.1074/jbc.M500963200

[26] Burchfield, J.S., Iwasaki, M., Koyanagi, M., Urbich, C., Rosenthal, N., Zeiher, A.M. and Dimmeler, S. (2008) Interleukin-10 from Transplanted Bone Marrow Mononuclear Cells Contributes to Cardiac Protection after Myocardial Infarction. Circulation Research, 103, 203-211. http://dx.doi.org/10.1161/CIRCRESAHA.108.178475

[27] Bock-Marquette, I., Saxena, A., White, M.D., Dimaio, J.M. and Srivastava, D. (2004) Thymosin Beta4 Activates Integrin-Linked Kinase and Promotes Cardiac Cell Migration, Survival and Cardiac Repair. Nature, 432, 466-472. http://dx.doi.org/10.1038/nature03000 
Scientific Research Publishing (SCIRP) is one of the largest Open Access journal publishers. It is currently publishing more than 200 open access, online, peer-reviewed journals covering a wide range of academic disciplines. SCIRP serves the worldwide academic communities and contributes to the progress and application of science with its publication.

Other selected journals from SCIRP are listed as below. Submit your manuscript to us via either submit@scirp.org or Online Submission Portal.
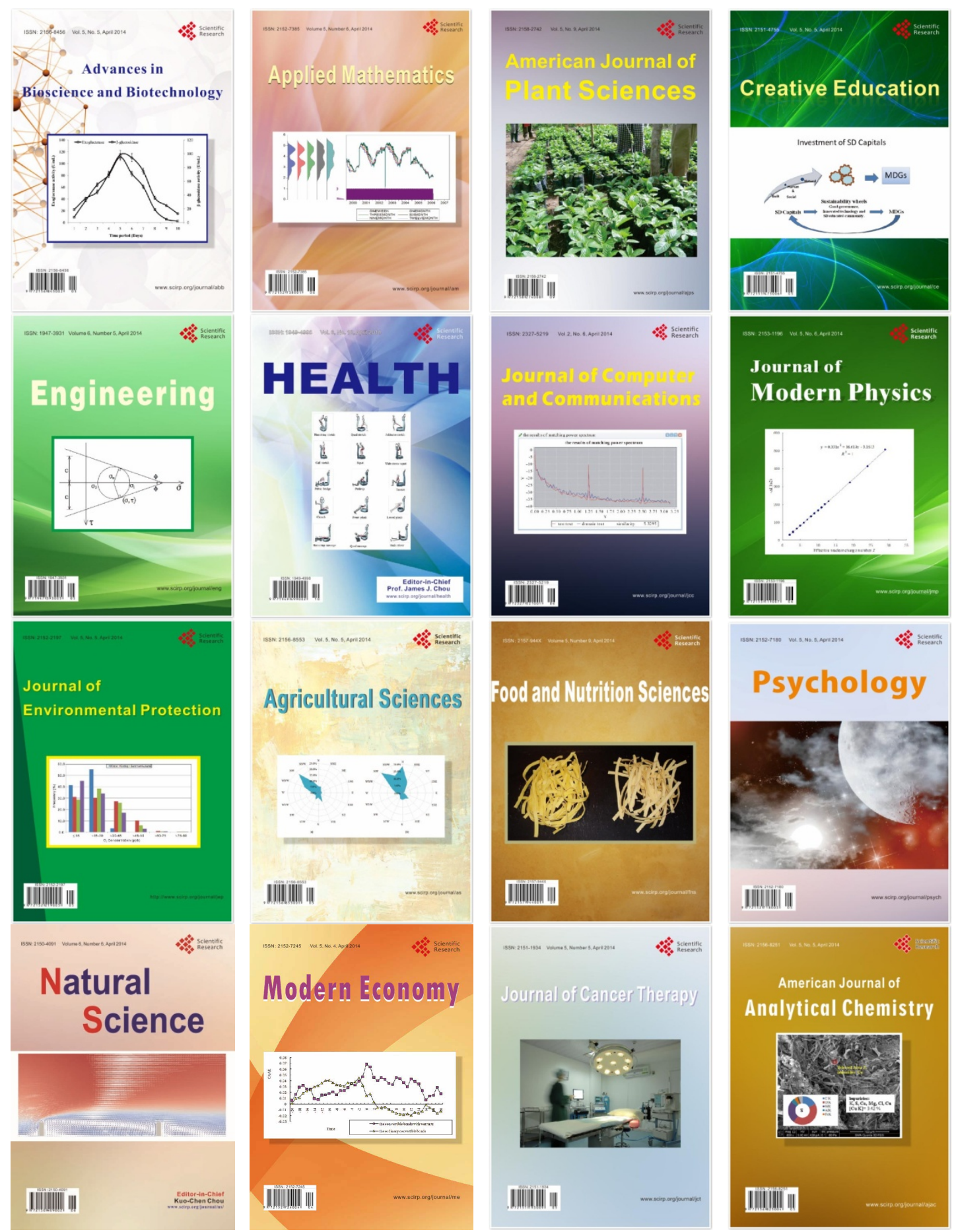